\title{
Increasing Community Legal Awareness About the Implementation of Islamic Sharia Law in the City of Sabang in Civic Esucation Perspective
}

\author{
Desi Oktaviana ${ }^{1, *}$, Prayoga Bestari ${ }^{2}$
}

\author{
1,2 Universitas Pendidikan Indonesia, Bandung, Indonesia \\ "Corresponding author.Email: oktavianadesi10@upi.edu
}

\begin{abstract}
There needs to be public awareness in applying the rules of Islamic Shari'a that the rules are made for themselves and the surrounding community. Awareness is not only a cognitive thing but is related to the reality of behavior in the surrounding environment. Violations of Islamic Shari'a are still common in Sabang. Life in a heterogeneous society is due to the more specialized the more diverse the participation as a result of the encounter of various cultures, moreover Sabang is one of the areas with foreign tourist destinations. The purpose of this study was to find out how to increase the legal awareness of the people of Sabang City in the implementation of Islamic Shari'a Law. This research uses a qualitative approach with a literature study method. The results of the study show that there are many ways to increase legal awareness of the people in Sabang City, namely through education and socialization in the community with formal and informal systems, but the most effective is through education. The need for synergy that occurs in the community in providing an understanding of this Shari'a legal awareness, so that it does not make the education sector the only one but is one of the many sectors that are shared responsibilities in increasing the legal awareness of the people of Sabang City.
\end{abstract}

Keywords: Islamic Sharia Law, Legal Awareness.

\section{INTRODUCTION}

The awareness of the people of Sabang in carrying out the rules of Islamic law is starting to be questioned. Based on the fact that there are still many violations of the Shari'a, both committed by community members around the tourism area, local tourists and foreign tourists.

Data on violations of Islamic Sharia in Sabang City

\begin{tabular}{|c|l|c|c|}
\hline No & Type of Violation & $\begin{array}{l}\text { Number of } \\
\text { Violations }\end{array}$ & Year \\
\hline 1 & Maisir (Gambling) & 5 Case & $2016-2021$ \\
\hline 2 & $\begin{array}{l}\text { Ikhtilath (kissing) } \\
\text { Khalwat } \\
\text { (Permissive) }\end{array}$ & 2 Case & 2019 \\
\hline
\end{tabular}

Table 1: Lestari, Diah Ayu Lestari Dan Ubaidullah $(2019: 5)$
Based on the results of research that has been carried out by Lestari [1] that the effectiveness of the implementation of Islamic law in Sabang is going well when viewed from several indicators regarding clear goals, strategies in achieving goals, good policy formulation and formulation, having suggestions and infrastructure, besides that it is also seen of the effectiveness of the program's operational and functional. Even though it has been running effectively, violations of Islamic law still occur.

In applying the rules regarding Islamic Sharia, it is necessary to have an awareness in the community that the rules made are for the good of themselves and the surrounding community. Because the Islamic Shari'a Law in question does not only concern oneself personally such as prayer, other people will not experience a loss if someone does not pray, as well as fasting, this has absolutely no effect on others. Prayer and Fasting are self-responsibility to His Lord. In contrast to the behavior of drunkenness, gambling and adultery, which do not only harm themselves but have the potential to harm others as well. Therefore, it requires awareness of oneself as an object regulated in 
Islamic law. Awareness itself can be interpreted as a determination to engage effectively with a goal.

The awareness referred to here is not only a cognitive thing but also relates to the reality of behavior that exists in the surrounding environment. Awareness requires continuous action that leads to completion in the affective domain. From the affective point of view, the development of values that can support good affective development can be done by inculcating social values in family and community life. Every family has its own standard of behavior that has a positive purpose for its children. The standards built by the family must be taught from an early age, because later the child will see the reality that exists in society with what he learns, the next thing the child will practice in a formal environment such as school or university where this has greatly impacted his life.

Therefore, the importance of the family and the surrounding climate in instilling ideals and knowledge of legal awareness begins at an early age. After the formation of an active legal understanding, legal compliance will naturally increase. A person is required to obey and obey the law which has the power of being coercive, binding and also regulating. The power that has a regulatory nature will make a person more educated within the legal framework. While the force that has a coercive nature will provide a deterrent effect because it gets strict sanctions for violators. Furthermore, a thought will arise whether the crime will subside if sanctions have been applied for violators of the rules? the existence of strict sanctions in fact does not fully make other people aware and obey the law.

Therefore, it is necessary to study more carefully about the objective conditions that exist in society, namely in the form of internal conditions that are psychological and cultural. The willingness of citizens to subjectively obey the law without coercion is one of the prerequisites for the realization of the law properly in everyday life. Without the willingness of citizens to voluntarily obey orders, it will result in the operation of the law in community life not being realized as expected. Threats in the form of sanctions no matter how hard it is proven cannot control the behavior of the subject as a whole.

Sabang itself is a city known for its maritime tourism area which is in great demand by foreign tourists and is the westernmost region in the territory of the Republic of Indonesia. Citizens are not easy to hold on to just a single commitment. Living in a heterogeneous society because of the increasingly specialized participation, the more diverse as a result of the encounter of various cultures, moreover Sabang is one of the areas with foreign tourist destinations. Commitments to complying with national laws often have to compete and even conflict with interests in other directions. Commitment is closely related to one's awareness to make which choices need to be prioritized. There are two aspects that include this, namely the cognitive aspect (aware of knowing), namely one's knowledge of whether or not there are rules about his actions. The second aspect is affective which leads to his emotional involvement in certain parties, which is based on his belief that what is known is what is right and should be done and obeyed. So based on this context, the researcher is interested in learning more about this topic.

\section{THEORETICAL REVIEW}

\subsection{Legal Awareness}

Legal awareness has the basic word "aware" which is defined as being aware, knowing and even understanding, Suharso and Retnoningsih [2] Realizing means knowing, realizing and feeling. Awareness in this case means realization, a state in which a person has understood, understood, the things that are felt or experienced.

Ewick and Silbey [3] state that awareness of the law is seen in the form of action and is a matter of practice which can be studied empirically, with the understanding that legal awareness is something related to "law as a behavior" not known as "law". as a norm or rule".

According to Soerjono Soekanto [4], according to him the legal awareness of the community is caused by the officials being less aware of their obligations to maintain the law and the lack of understanding of the goals and functions of development.

\subsection{Legal Awareness Indicator}

Legal awareness has four indicators, each of which is a stage as follows:

a. Legal knowledge is a person's understanding of the behavior or actions contained in the regulations. This knowledge is interrelated with prohibited behavior or behavior permitted by law. for example, as in the surrounding environment that in general people already know and understand that molesting, killing and stealing are behaviors that are prohibited and have sanctions if they are still carried out. Legal awareness is similar to Legal Fiction in that it assumes that everyone knows the contents of the newly implemented law.

b. Legal understanding is one's understanding of the contents of legal regulations. Legal understanding is a concept that a person understands about the content and purpose of a regulation, whether it is a written regulation or not, and understands the benefits of the regulation for himself and his environment. 
c. Legal attitude is a tendency for a person to accept the law/rule as something that is useful or provides benefits for himself and his environment if the law is obeyed.

d. Legal behavior, which is a pattern of legal behavior, is the most important thing to see the legal awareness of a community because this is where it can be seen whether a regulation is able to apply or not in people's lives.

\subsection{Islamic Sharia Law}

Shari'ah itself has two meanings, first in a narrow sense, shari'ah is one of the important perspectives related to law. while the understanding of shari'ah in a broad sense covers all aspects of Islamic teachings. Furthermore, Islamic law is used in a wider scope such as economic, cultural, educational, political and other aspects. The legal basis why Aceh is able to implement Islamic Sharia in social life is based on Law no. 44 of 1999[5] and Law no. 18 of 2001[6] in article 31 that "The provisions for the implementation of this law concerning the authority of the Provincial Government of Nanggroe Aceh Darussalam are stipulated by the Qanun of the Province of Nanggroe Aceh Darussalam".

In addition to the form of legislation as a form of firmness and seriousness of the government in the application of Islamic Sharia, Aceh has also implemented a redesign in terms of existing education, this is done to facilitate the implementation of Sharia. The redesign referred to here is to redesign the education format which so far is not only a dichotomy between general and religious educational institutions, but also the distance between the three educational centers. Therefore, in addition to combining the two educational institutions, it also encourages three educational centers (tri centers) to be able to synergize effectively, namely schools (formal) community (nonformal) and family (informal), AN-Nahwali [7]

Muhammad Ali said, the law can be said to be ineffective if there are still many people who have not obeyed the law, but if many people have complied with the rule of law but the quality of the law is still questionable, it is because this is because the obedience of the law itself can still be distinguished. in three types as stated by H.CKelman (Doris, 2018: 725-726) [8] namely:

a) Compliant obedience is when someone does something because they are terrified of being punished.

b) Obedience that is identification occurs when a person follows a rule out of fear of damaging excellent relationships with others. c) Internalization of compliance occurs when a person follows a regulation because he believes the rules are consistent with the intrinsic values he has adopted.

\section{METHOD}

The design of this research is Literature Review or literature review. Library research or literature review (literature review, literature research) is a series of studies related to library data collection methods, or research whose research objects are explored through various library information (books, encyclopedias, scientific journals, newspapers, magazines, and documents), Nana [9].

The nature of this research is descriptive analysis, namely the regular breakdown of the data that has been obtained, then understanding and explanation are given so that it can be understood well by the reader.

Literature review is a research conducted by researchers by collecting a number of books, magazines related to the problem and research objectives. This technique is carried out with the aim of revealing various theories that are relevant to the problems being faced/researched as reference material in the discussion of research results. Literature review can be carried out from several sources, such as national and international journals.

When the goal is to present an overview of a particular subject or research challenge, literature reviews are valuable. This form of literature evaluation is commonly used to assess the current level of knowledge on a certain issue. It may be used to generate research agendas, identify research gaps, or just debate a particular topic. If the goal is to engage in theory development, literature reviews might be helpful. (Snyder, 2019:334). [10]

\section{RESULTS AND DISCUSSION}

\section{a. Legal Awareness Raising Plan}

Law is a reflection or a reflection of the values contained in society. Instilling legal awareness means instilling cultural values. And cultural values can be achieved by education. Therefore, after knowing the possible causes of the decline in public legal awareness, the main, effective and efficient improvement and development effort is Mertokusumo education [11]

1. Through education, namely formal and non-formal education. Education is a continuous and intensive activity and especially in terms of legal awareness education it will take a long time. It would not be an exaggeration to say that with intensive education as a result of increasing and fostering legal awareness, we can only see satisfactory results in at least another 18 or 19 years, Mertokusumo [12] Various important 
things are inculcated in the education process as follows:

1) It is instilled about how to be a good Indonesian society, about what are the rights and obligations of an Indonesian citizen. Every citizen should know about the laws in force in our country.

2) Instill about obeying, implementing, enforcing and defending it,

3) Further instilling the understanding that in our social life we must not violate the law and must comply with legal obligations, as well as to realize and practice it.

4) It is instilled that it is not permissible to do harm to others and to act cautiously in society towards other people,

5) Need to be invested more intensively: the rights and obligations of Indonesian citizens, the structure of our country, Pancasila and the Constitution, important articles of the Criminal Code, as well as the Qanun of Islamic Shari'a applicable in the region,

6) How to obtain legal protection,

7) It is necessary to hold various school regulations that must be obeyed,

8) Every violator must be punished. with the supervision of teachers who will prosecute violators of school rules.

Pancasila and Citizenship Education is one example of a form of formal education in schools that has a role in the formation of legal awareness of school-age youth. According to Branson [13], the purpose of civic education is the participation of qualified citizens who are also responsible in political and social life, both at the local and state levels. Based on the objectives of civic education above, it can be concluded that the purpose of Civics is to equip the ability of students in terms of responsibility as citizens who believe and are devoted to God Almighty, think critically and rationally, participate actively in the life of the nation and state. also form themselves into a person with character in accordance with the Indonesian people. Sapriya [14] added that the purpose of civic education is to form citizens who have full participation of reason and are responsible in political life and also obey the values and basic principles of Indonesian democracy. Effective and responsible participation is further developed in the direction of certain dispositions or characters that influence in increasing the ability of individuals to participate in political process activities and contribute to providing support for a good political system and improvement in society.

2. Getting used to the implementation of the Regulation of the Minister of Law and Human Rights of the
Republic of Indonesia Number M.01.PR.08.10 of 2007 concerning the Pattern of Legal Counseling [15] and the Regulation of the Head of the National Legal Development Agency (BPHN) No. 03.05.73 of 2008 concerning the Formation and Fostering of Conscious Families Law and village/kelurahan are aware of the law [16]. (KADARKUM) Legal Awareness Family, hereinafter abbreviated as Law Aware Family, is one method of legal education as a forum that functions to gather citizens of their own accord to seek to foster legal awareness for themselves. This is one form of counseling that is carried out within the scope of the family and also the community. (Laskarwati) [17]. For example: (1) Increasing campaigns on legal awareness at the level of formal education, (2) Increasing the legal awareness week program, (3) Increasing writing competitions, or mottos related to legal awareness. (4) Increase appreciation for citizens who comply with the laws and regulations. (5) Improving legal counseling to Kadarkum through lectures, discussions, meetings, simulations and so on. (6) Increasing legal counseling through: radio, television, videos, magazines, newspapers, films, and so on. (7) Increase legal counseling in the form of reading materials, especially illustrated stories or heroic strips. (8) Increase public legal awareness campaigns/exhibitions, namely providing books, brochures and leaflets in addition to showing films, slides, VCDs and so on which are visualizations of legal awareness that will have great public appeal.

Creating public services by a legal structure that is professional, consistent, fair, accountable and transparent.

3. It is necessary to build a coordination network across government and private institutions that specifically design various programs regarding public legal awareness regarding awareness of Islamic Shari'a law. Private institutions can be in the form of tourist management places which are one of the places visited by many tourists, both domestic tourists and foreign tourists.

4. The creation of legal rules that are in accordance with the laws that live in society as well as the people of Aceh who have long lived with religious values, the Qanun Jinayat was formed which is one form of the government's seriousness in maintaining the values of Islamic law in Aceh, especially in Aceh. The city of Sabang which is one of the areas visited by many foreign tourists which provides the possibility of a different cultural shift and is not 
in accordance with the values that exist in society.

5. Improving the performance of law enforcement officers that are consistent, objective, and not favoritism in enforcing the law.

6. In the end, in an effort to succeed in increasing public legal awareness, the most important thing is the participation of officials and leaders.

7. It is time for a law learning program to be carried out in various schools in various villages and sub-districts both at the elementary, junior and senior high school levels. Legal learning materials use uniform modules that are tailored to the level or level of education.

8. Legal learning materials at the elementary level are focused on the first indicator is legal knowledge. In this case, elementary school students are expected to know that certain behaviors have been regulated by law. The legal regulations referred to here are written law and unwritten law. This behavior involves behavior that is prohibited by law and behavior that is permitted by law.

9. Legal learning materials at the junior high school level are focused on indicators of legal understanding. Legal understanding is intended for junior high school students to have knowledge and understanding of certain rules, for example the existence of correct knowledge and understanding from the community about the nature and importance of Aceh Qanun No. 6 of 2014 concerning Jinayat Law [18]

10. Legal learning materials at the senior high school level are focused on indicators of legal attitudes and legal behavior. In this connection, students are expected to tend to make certain judgments about the law and behave legally or comply with applicable regulations.

\section{b. Stages of the extension program}

In the activities of the legal counseling program for the community, the following are some of the stages that must be considered, namely:

1. Determining the Target of Extension As it is understood that every village/kelurahan consists of various levels of society that can be the target of legal counseling for the creation of a lawconscious village or a law-aware village. The objectives of the legal counseling are:

1) Family

2) School (elementary, junior high, high school).

3) Government institutions (Offices of government-owned institutions)
4) Institutions (private offices, foundation companies, etc.).

Tjeppy [19] revealed that increasing legal awareness must start from education. Good education will produce people who are responsible, tolerant, and care about the environment. Legal awareness among students is very important. High legal awareness between lessons can provide comfort and discipline, especially in schools and in society in general.

\section{CONCLUSION}

Growing legal awareness of the most influential community is through education in various ways, namely formal, informal and non-formal. In the Formal Path, namely through education in schools, it can be through Civics lessons which have the aim of making citizens who are responsible (civic responsibility). The Informal Path, namely the community and government agencies, can use the Legal Awareness Family (KADARKUM) method, which is one method of legal education as a forum that functions to gather citizens of their own accord to seek to foster legal awareness for themselves. This is one form of counseling that is carried out within the scope of the family and also the community. Non-formal is a family by instilling the values of Islamic law and also obedience to the law for the common good.

\section{ACKNOWLEDGMENTS}

Sharia: Religious law that stipulates the rules of human life, human relations with Allah SWT, human relations with humans and the natural environment based on the Qur'an and hadith

Maisir: Actions that contain elements of betting and/or elements of luck carried out between 2 (two) or more parties, accompanied by an agreement that the winning party will receive certain payments/benefits from the losing party either directly or indirectly.

Ikhtilath: Intimate acts such as making out, touching, hugging and kissing between men and women who are not husband and wife with the willingness of both parties, either in closed or open places.

Khalwat: The act of being in a closed or hidden place between 2 (two) people of different sexes who are not Mahrams and without marital ties with the willingness of both parties which leads to adultery. 
Mahram: people who are forbidden to be married forever, namely biological parents and so on up, step parents, children and so on down, stepchildren from wives who have had intercourse, siblings (biological, father and mother), breast-feeding siblings, father and nursing mother, father's brother, mother's brother, brother's son, in-laws (male and female), son-in-law (male and female).

Jarimah: Acts that are prohibited by Islamic Shari'a which in this Qanun are threatened with 'Uqubat Hudud and/or Ta'zir.

'Uqubat: punishment that can be imposed by the judge against the perpetrators of Jarimah.

Hudud: the type of 'Uqubat whose shape and size have been explicitly specified in the Qanun.

\section{REFERENCES}

[1] Lestari, Diah Ayu dan Ubaidullah. (2019). Efektivitas Penerapan Syariat Islam Di Kawasan Pariwisata Kota Sabang (Studi Kasus Dinas Syariat Islam). Jurnal Ilmiah Mahasiswa FISIP Unsyiah. Volume 4, Nomor 2. Hal (1-12)

[2] Rosana, Ellya. (2014). Kepatuhan Hukum Sebagai Wujud Kesadaran Hukum Masyarakat. Jurnal Tapis Vol.10 No.1 (1-25)

[3] Hasibuan, Z. (2013). Kesadaran Hukum Dan Ketaatan Hukum Masyarakat Dewasa Ini. Jurnal Justitia (Jurnal Ilmu Hukum dan Humaniora). Vol. 1 No 1. hal 78-92

[4] Tutik, Triwulan Titik. (2006). Pengantar Ilmu Hukum. Surabaya: PT. Prestasi Pustaka

[5] UU No. 44 tahun 1999 Tentang Keistimewaan Aceh

[6] UU No. 18 tahun 2001 Tentang Otonomi Khusus Aceh

[7] Nurdin, Abidin. dkk. (2020). Redesain Pendidikan Islam: Perkembangan Pendidikan Pasca Penerapan Syari'at Islam Di Aceh. EKSPOSE: Jurnal Penelitian Hukum dan Pendidikan. Vol. 19, No. 1, Juni 2020, pp. 997-1007

[8] Doris Hadiana. (2018). The Role of Police Institutions in the Handling of Criminal Actions. International Journal of Science and Research (IJSR). https://www.ijsr.net/get_abstract.php?paper id=ART2018120, Volume 7 Issue 2, February 2018, $724-730$
[9] Nana Syaodih. 2009. Metode Penelitian Pendidikan. PT. Remaja Rosdakarya: Bandung

[10] Snyder, Hannah. (2019). Literature review as a research methodology: An overview and guidelines. Journal of Business Research. 104 (2019) 333-339

[11] Ahmad, Ibrahim. (2018). Rencana Dan Strategi Peningkatan Kesadaran Hukum Masyarakat. Gorontalo Law Review. Vol. 1 Nomor 1. 15-24

[12] Ahmad, Ibrahim. (2018). Rencana Dan Strategi Peningkatan Kesadaran Hukum Masyarakat. Gorontalo Law Review. Vol. 1 Nomor 1. 15-24

[13] Branson, S Margaret. (1999). Belajar Civic Education dari Amerka. Yogyakarta: Lkis

[14] Sapriya. (2000). Studi Sosial Konsep dan Pembelajaran. Bandung: Rimdi Press

[15] Peraturan Menteri Hukum dan HAM RI Nomor M.01.PR.08.10 Tahun 2007 Tentang Pola Penyuluhan Hukum

[16] Peraturan Kepala Badan Pembinaan Hukum Nasional (BPHN) No.03.05.73 Tahun 2008 Tentang Pembentukan dan Pembinaan Keluarga Sadar Hukum dan desa/kelurahan sadar hukum

[17] Prayogo, B.E., Amanah, A., Pradana, T.M.W., \& Rodiyah, R.'Increasing Legal Capacity for Communities in the Context of Realizing a Village of Law Awareness and Child Friendly.'.(2019). Indonesian Journal of Advocacy and Legal Services,1(1), 65-78. DOI: 10.15294/ijals.v1i1.33776

[18] Qanun Aceh No. 6 Tahun 2014 tentang Hukum Jinayat

[19] Tjeppy, T. (2021). Learning civic education on students' legal awareness. Jurnal Civics: Media Kajian Kewarganegaraan, 18(1), 97-108. DOI: https://doi.org/10.21831/jc.v18i1.38602 